\title{
USE OF BLOGS FOR PROSPECTIVE EARLY CHILDHOOD TEACHERS
}

\section{(UTILIZACIÓN DE LOS BLOGS POR FUTUROS DOCENTES DE EDUCACIÓN INFANTIL)}

Pablo-César Muñoz-Carril

Universidad de Santiago de Compostela

Mercedes González-Sanmamed

Universidad de A Coruña

Eduardo-José Fuentes-Abeledo

Universidad de Santiago de Compostela

DOI: 10.5944/educXX1.23768

\begin{abstract}
How to reference this article/ Cómo referenciar este artículo:
Muñoz-Carril, P.C.; González-Sanmamed, M., \& Fuentes-Abeledo, E.J. (2020). Use of blogs for prospective early childhood teachers. Educación XX1, 23(1), 247-273, doi: 10.5944/ educXX1.23768

Muñoz-Carril, P.C.; González-Sanmamed, M., y Fuentes-Abeledo, E.J. (2020). Utilización de los blogs por futuros docentes de educación infantil. Educación XX1, 23(1), 247-273, doi: 10.5944/ educXX1.23768
\end{abstract}

\section{ABSTRACT}

This study examines those factors which affect the possibility of using blogs as a tool for continued learning by future infant-school teachers. 222 students participated ( 3 cohorts spread over 13 class groups) who were in basic infant teacher training classes in a Spanish university. The students, following their experience using blogs throughout the course, responded to a self-administered electronic questionnaire that had been previously validated. A model was created underpinned by various constructs which produced relevant hypotheses based on social-cognitive theory and the technology acceptance model. The partial least squares (PLS) method was used to examine the proposed hypotheses, of which ten were accepted. 
The results indicated that the variables which significantly contributed to students continuing to use blogs to learn were perceived self-efficacy, personal outcome expectations, perceived support for enhancing social ties, along with perceived usefulness, perceived ease of use, attitude and perception of playfulness. The results are discussed and compared with results of other similar research, which allowed the model's predictive capacity to be replicated and confirmed). Finally, the study provides useful recommendations based on the findings for those teachers who want to use blogs with their university students. and want their students to using them in their learning.

\section{KEY WORDS}

Blogs; students; early childhood education; initial training; higher education; learning.

\section{RESUMEN}

En esta investigación se analizan aquellos factores que inciden en la posibilidad de uso de los blogs como herramienta para continuar aprendiendo por parte de quienes van a ser futuros docentes en el ámbito de educación infantil. En el estudio participaron un total de 222 estudiantes (pertenecientes a 3 cohortes distribuidas en 13 grupos de aula) que cursaron una asignatura de formación básica perteneciente al grado de maestro de educación infantil en una universidad española. El alumnado, tras su experiencia a lo largo del curso en el uso de blogs, respondió a un cuestionario electrónico auto-administrado y previamente validado. Se elaboró un modelo sustentado por diversos constructos que dieron lugar a hipótesis relevantes derivadas primordialmente de la teoría socio-cognitiva y del modelo de aceptación tecnológica. Se utilizó la técnica de mínimos cuadrados parciales (PLS) para el contraste de las doce hipótesis planteadas, de las cuales se aceptaron diez. Los resultados indican que la auto-eficacia percibida, las expectativas de resultados personales, el apoyo percibido para mejorar los vínculos sociales, así como la percepción de utilidad, la facilidad de uso percibida, la actitud y la percepción de alegría y disfrute, son variables significativas que contribuyen a que los estudiantes continúen utilizando los blogs como mecanismo para aprender. Asimismo, se discuten y comparan los resultados obtenidos con otras investigaciones internacionales similares, lo que ha permitido replicar y confirmar la capacidad predictiva del modelo. Finalmente, se aportan recomendaciones útiles, derivadas de los hallazgos obtenidos, para aquellos docentes que pretendan utilizar blogs con sus 
PABLO-CÉSAR MUÑOZ-CARRIL, MERCEDES GONZÁLEZ-SANMAMED,

estudiantes universitarios, a fin de que estos usen dichas herramientas para desarrollar sus aprendizajes.

\section{PALABRAS CLAVE}

Blogs; estudiantes; educación infantil; formación inicial; educación superior; aprendizaje.

\section{INTRODUCTION}

Technological advances have led to radical social transformations which demand more flexible, diverse, and open learning. Various authors (González-Sanmamed, Sangrà, Souto-Seijo, \& Estévez, 2018; Jackson, 2016) have talked about the concept of learning ecologies to refer to the characteristics of what is learned and how it is learned nowadays. The influence of factors such as network connectivity, empowerment of students, overcoming geographical and spatial barriers, and the importance of nonformal and informal learning is leading to a transformation in learning.

New learning formats need a qualitative and quantitative broadening of teaching competencies and call for both initial and continuing teacher education and training to be able to respond to the educational demands that society in general, and students in particular, will pose. It is worth highlighting the importance of generating innovative training spaces in which technology becomes a learning tool during initial teacher education and even more importantly, promoting the ownership of these resources to encourage continual professional development and learning.

Blogs are widely recognised for their contributions to the training process. The value of blogs as instruments of learning has been noted in various studies which have also demonstrated their contribution to the development of digital skills (Pinya, Tur, \& Roselló, 2016). Most research on blogs has focused on their use, uptake and impact on learning in university students (Avci \& Askar, 2012; Cakir, 2013; Sullivan \& Longnecker, 2014; Garcia, Moizer, Wilkins, \& Haddoud, 2019). There is also literature about the potential and challenges of collaborative projects linked to blogs (Cho, Lim, \& Lee, 2017) and about their importance in establishing and maintaining collaborative learning networks and encouraging reflection (Khan, 2017). In the Spanish context, several studies on the use of blogs in education have also been carried out. In particular, in secondary education, the use of these tools has been analysed with regard to the academic performance of adolescents (García-Martín \& Cantón-Mayo, 2019) and also as a mechanism 
to enable collaborative learning, as well as to improve the students' writing skills (Álvarez \& Bassa, 2013). In Higher Education, investigations such as those developed by Durán-Medina (2011) show how blogs can contribute to the improvement of educational praxis and, at the same time, serve as a teaching strategy. Other studies also located in the university field have shown the usefulness of blogs as a tool for reflection, especially in teacher training (Marín-Díaz, Gómez-Parra, 2015; Muñoz-Carril, 2019).

Beyond that research, there has been interest in illuminating those factors which affect the intention to using blogs as mechanisms of learning (Ifinedo, 2018a, 2018b; Hung, Tsai, \& Chou, 2016). In addition to examining students' interest in continuing to use blogs, in this study the model defined by Ifinedo (2017) is used to identify significant factors behind positive effects of technology on learning.

Part of the relevance of this research comes from the lack of research looking at the intention to keep using blogs for learning, and there is particular relevance in the originality of doing the research in the context of the initial training of future infant-school teachers (teachers being trained to teach children from 3-6 years old). It is also worth highlighting the value of adapting a theoretical model and adopting an empirical approach which had already been recognised by the international scientific community (Ifinedo, 2017, 2018a, 2018b).

\section{Research model and hypothesis}

Social-cognitive theory (Bandura, 1986) and the technology acceptance model (Davis, 1989) were fundamental reference frameworks for the creation of the research model, as well as for the various hypotheses, allowing us to identify the factors affecting undergraduate students' intentions to using blogs for learning (Figure 1). Both theories have been shown to be particularly useful in constructing models of adoption of technological tools such as blogs in the context of higher education (see, for example: Ifinedo 2018a, 2018b; Lai, Wang, \& Lei, 2012). 


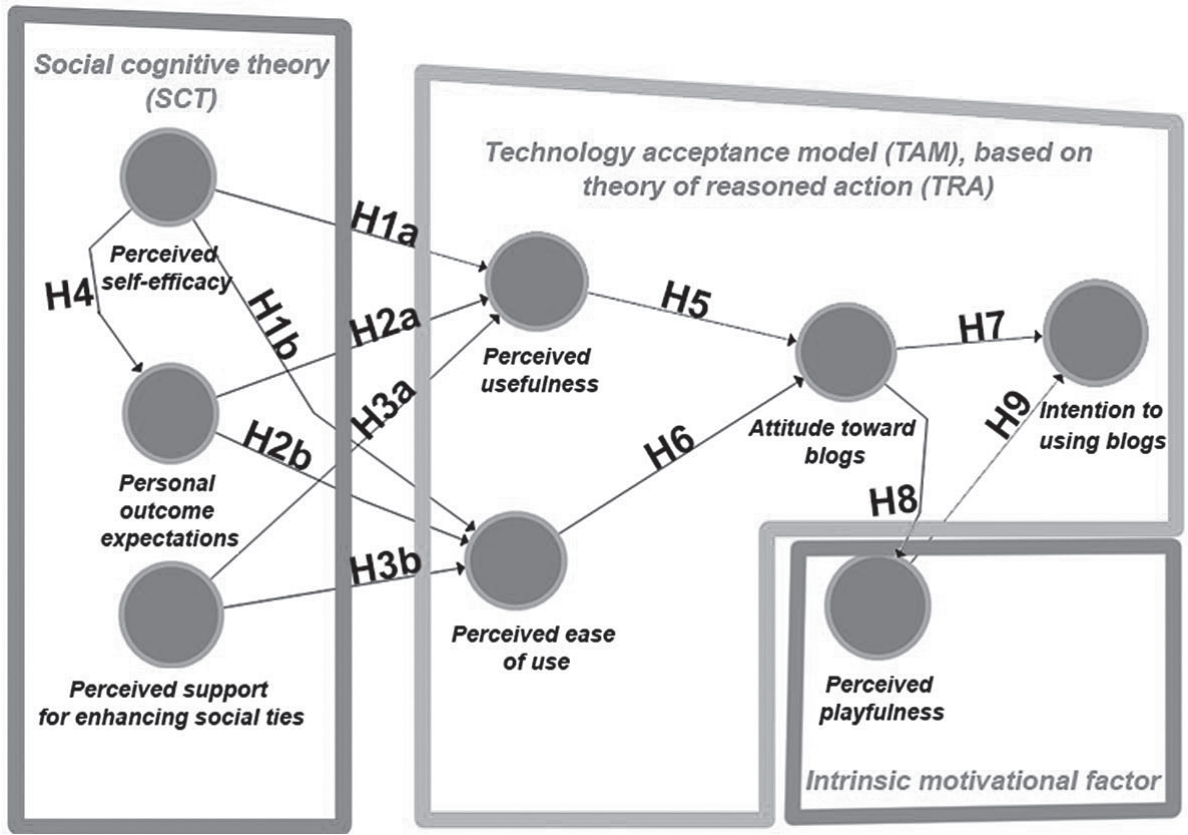

Figure 1. Research model. Adapted from Ifinedo (2017)

The constructs that were addressed within the framework of socialcognitive theory were perceived self-efficacy, personal outcome expectations and perceived support for enhancing social ties. They have been used in other research related to the intention to using blogs as learning technologies (Ifinedo, 2017).

According to Rohatgi, Scherer, and Hatlevik (2016), self-efficacy is closely related to expectations of future success and failure, which in turn affects students' choices and behaviour. For Ashtari and Eydgahi (2017), self-efficacy significantly affects perceptions of the usefulness of technology as well as its perceived ease of use.

Personal outcome expectations refers to an individual's judgement about their ability to do what is needed to achieve desired results, while perceived support for enhancing social ties refers to perceptions about how close the connections are between a person and the members of their group (Bandura, 1986). Various studies, for example by FernándezCardador, Hernández-García, \& Iglesias-Pradas (2014), have demonstrated the positive, significant influence of both variables on the perception of usefulness, and although one might expect expectations of personal results to correlate with ease of use when it comes to blogs, these authors showed that there was no positive effect. 
The following hypotheses were drawn up based on aspects of socialcognitive theory:

- H1a. The level of perceived self-efficacy has a significant, positive effect on the perception of the usefulness of blogs for learning.

- H1b. The level of perceived self-efficacy has a significant, positive effect on the perceived ease of use of blogs as tools for learning.

- H2a. Personal outcome expectations have a significant, positive effect on the perception of usefulness of blogs as tools for learning.

- H2b. Personal outcome expectations have a significant, positive effect on the perceived ease of use of blogs as tools for learning.

- H3a. Perceived support for enhancing social ties has a significant, positive effect on the perception of the usefulness of blogs as tools for learning.

- H3b. Perceived support for enhancing social ties has a significant, positive effect on the perceived ease of use of blogs for learning.

- H4. Perceived self-efficacy has a significant, positive effect on personal outcome expectations in relation to the use of blogs as learning resources.

Three key constructs in the technology acceptance model (Davis, 1989) help to explain students' intentions tousing blogs: perceived usefulness, ease of use, and attitude towards blogs. These factors have been shown to be robust predictors (Lai, et al., 2012). In addition, research such as that by Lin and Li (2014) shows that a positive attitude towards blogs increases perceived levels of enjoyment (playfulness) in using these tools for learning (which suggests an intrinsic motivation), and in turn, increases the relative probability of using blogs.

This has led to the following hypotheses:

- H5. Perceived usefulness has a significant, positive effect on attitudes about using blogs for learning.

- H6. Perceived ease of use has a significant, positive effect on attitudes about using blogs for learning.

- H7. The attitude towards using blogs has a positive effect on the intention to using blogs for learning. 
- H8. The attitude towards using blogs in learning contexts has a significant, positive effect on students' perceived playfulness.

- H9. The perception of playfulness has a significant, positive effect on the intention to using blogs.

\section{RESEARCH METHOD}

\section{Participants and procedures}

A total of 222 students volunteered to participate from those who were doing the first year Processes of improvement and use of ITC course as part of a degree in infant teaching (this represented 95\% of students doing the course). This subject is developed in the Faculty of Teacher Training at the University of Santiago de Compostela (Campus Terra) and in the curricular structure of the study plan it appears as a subject of basic training with a load of 6 ECTS credits, which means a total of 150 hours of work for students both in the classroom and outside. Also, the subject is structured into lectures, interactive classes and mentoring. Among the different practices and projects to be carried out, the students created and managed their own blogs under the guidance of their teachers as a means of reflection, acquiring subject knowledge, and developing their digital skills (Deng \& Yuen, 2011).

After proposing the study, and assuring participants of confidentiality, we collected data from 3 cohorts (spread over 13 groups) via a selfadministered electronic questionnaire in the ICT classroom during class time.

The vast majority $(90.5 \%)$ of the participants were women, and the remaining $9.5 \%$ men. This asymmetry is relatively common in teacher training courses, especially in infant teacher training. In terms of age, $15.3 \%$ were under $18,54.1 \%$ were between 19 and $21,20.7 \%$ were between 22 and $24,5.4 \%$ were between 25 and 27 , and $4.5 \%$ were over 27 . About two thirds $(66.2 \%)$ of interviewees reported never having created their own blog before.

\section{Instrument}

In order to ensure content validity of the constructs making up the proposed model, items were used from scales that had been previously validated and widely substantiated in research on this topic (Ifinedo, 2017; 
Ifinedo, 2018a, 2018b). Before the instrument was applied, it was reviewed by a panel of five experts in educational technology. A pilot study was also carried out to validate the questionnaire with 25 students who had created their own blogs, so that they were able to provide comments on item comprehensibility, time needed to complete the questionnaire, and issues related to format and presentation.

A seven-point Likert-type scale was used with answers ranging from totally disagree (1) to totally agree (7). Table 1 shows the descriptive statistics of the items used and the relevant constructs.

Table 1

Questionnaire items and descriptive statistics

\begin{tabular}{|c|c|c|c|c|}
\hline Construct & Item $\mathbf{N}^{\mathbf{o}}$ & Description & Mean & $\begin{array}{l}\text { Standard } \\
\text { Desviation }\end{array}$ \\
\hline \multirow{4}{*}{$\begin{array}{l}\text { Perceived } \\
\text { self-efficacy }\end{array}$} & PSEF_1 & $\begin{array}{l}\text { I am confident in } \\
\text { my ability to provide } \\
\text { information through a } \\
\text { blog that could help my } \\
\text { classmates understand } \\
\text { concepts and topics about } \\
\text { processes of improving } \\
\text { and using ITC in infant } \\
\text { education. }\end{array}$ & 5.45 & 1.01 \\
\hline & PSEF_2 & $\begin{array}{l}\text { I am confident in my } \\
\text { ability to be able to } \\
\text { provide information in a } \\
\text { blog that my classmates } \\
\text { will find useful. }\end{array}$ & 5.55 & 0.99 \\
\hline & PSEF_3 & $\begin{array}{l}\text { I can create a blog to } \\
\text { share information (news, } \\
\text { resources, ideas...) } \\
\text { related to processes of } \\
\text { improvement and use of } \\
\text { ITC in infant education. }\end{array}$ & 5.90 & 1.02 \\
\hline & PSEF_4 & $\begin{array}{l}\text { In general, I have a high } \\
\text { level of ability to use blogs } \\
\text { to do assigned tasks in my } \\
\text { processes of improvement } \\
\text { and use of ITC course. }\end{array}$ & 5.36 & 1.04 \\
\hline
\end{tabular}




\begin{tabular}{|c|c|c|c|c|}
\hline Construct & Item $\mathbf{N}^{\mathbf{O}}$ & Description & Mean & $\begin{array}{l}\text { Standard } \\
\text { Desviation }\end{array}$ \\
\hline \multirow{4}{*}{$\begin{array}{c}\text { Perceived } \\
\text { ease of use }\end{array}$} & PEOU_1 & $\begin{array}{l}\text { It is quite easy for me to } \\
\text { run a blog. }\end{array}$ & 5.11 & 1.26 \\
\hline & PEOU_2 & $\begin{array}{l}\text { Learning to use blogs is } \\
\text { easy for me. }\end{array}$ & 5.22 & 1.33 \\
\hline & PEOU_3 & $\begin{array}{l}\text { It seems easy to me } \\
\text { to use blogs to learn } \\
\text { concepts related to the } \\
\text { improvement and use of } \\
\text { ITC in infant education. }\end{array}$ & 5.44 & 1.14 \\
\hline & PEOU_4 & $\begin{array}{l}\text { In general, I think it } \\
\text { is easy to use blogs to } \\
\text { support my learning } \\
\text { about the use of ITC in } \\
\text { infant education. }\end{array}$ & 5.53 & 1.14 \\
\hline \multirow{4}{*}{$\begin{array}{l}\text { Perceived } \\
\text { usefulness }\end{array}$} & PUSS_1 & $\begin{array}{l}\text { The use of blogs has } \\
\text { improved my knowledge } \\
\text { of the use of ITC in infant } \\
\text { education. }\end{array}$ & 5.89 & 1.03 \\
\hline & PUSS_2 & $\begin{array}{l}\text { Using blogs in the } \\
\text { processes of improvement } \\
\text { and use of ITC course } \\
\text { has improved the } \\
\text { effectiveness of my } \\
\text { learning in topics covered } \\
\text { in this subject. }\end{array}$ & 5.72 & 0.95 \\
\hline & PUSS_3 & $\begin{array}{l}\text { Using blogs has helped } \\
\text { me to better learn aspects } \\
\text { related to using ITC in } \\
\text { infant education. }\end{array}$ & 5.74 & 0.96 \\
\hline & PUSS_4 & $\begin{array}{l}\text { Creating my own blog } \\
\text { in this processes of } \\
\text { improvement and use of } \\
\text { ITC in infant education } \\
\text { course, has helped me } \\
\text { to better understand the } \\
\text { educational uses of this } \\
\text { tool in infant education. }\end{array}$ & 5.93 & 1.02 \\
\hline
\end{tabular}




\begin{tabular}{|c|c|c|c|c|}
\hline Construct & Item $\mathbf{N}^{o}$ & Description & Mean & $\begin{array}{l}\text { Standard } \\
\text { Desviation }\end{array}$ \\
\hline \multirow{4}{*}{$\begin{array}{c}\text { Perceived } \\
\text { playfulness }\end{array}$} & PPLY_1 & $\begin{array}{l}\text { I feel that using blogs } \\
\text { in the processes of } \\
\text { improvement and use of } \\
\text { ITC course has improved } \\
\text { my imagination. }\end{array}$ & 5.07 & 1.32 \\
\hline & PPLY_2 & $\begin{array}{l}\text { I feel that blogs help to } \\
\text { stimulate my curiosity. }\end{array}$ & 5.32 & 1.38 \\
\hline & PPLY_3 & $\begin{array}{l}\text { Using blogs in the } \\
\text { processes of improvement } \\
\text { and use of ITC course has } \\
\text { been enjoyable. }\end{array}$ & 5.22 & 1.36 \\
\hline & PPLY_4 & $\begin{array}{l}\text { Using blogs in the } \\
\text { processes of improvement } \\
\text { and use of ITC course has } \\
\text { been fun. }\end{array}$ & 4.61 & 1.55 \\
\hline \multirow{3}{*}{$\begin{array}{c}\text { Personal } \\
\text { outcome } \\
\text { expectations }\end{array}$} & POUT_1 & $\begin{array}{l}\text { If the information in my } \\
\text { blog is good, I will be } \\
\text { viewed more favourably } \\
\text { in the course. }\end{array}$ & 5.03 & 1.33 \\
\hline & POUT_2 & $\begin{array}{l}\text { If the content of my blog } \\
\text { is interesting, I will get } \\
\text { recognition from the } \\
\text { teachers. }\end{array}$ & 5.29 & 1.37 \\
\hline & POUT_3 & $\begin{array}{l}\text { If the work on my blog is } \\
\text { good, I will be rewarded } \\
\text { for my efforts. }\end{array}$ & 5.93 & 1.10 \\
\hline \multirow{5}{*}{$\begin{array}{l}\text { Attitude } \\
\text { toward } \\
\text { blogs }\end{array}$} & ATTI_1 & $\begin{array}{l}\text { I enjoy participating in } \\
\text { blogs. }\end{array}$ & 5.20 & 1.36 \\
\hline & ATTI_2 & Blogging ins a good idea. & 5.59 & 1.26 \\
\hline & ATTI_3 & Blogging is a pleasure. & 4.65 & 1.47 \\
\hline & ATTI_4 & $\begin{array}{l}\text { I like the idea of blogging } \\
\text { to learn. }\end{array}$ & 5.59 & 1.34 \\
\hline & ATTI_5 & Blogging motivates me. & 4.98 & 1.44 \\
\hline
\end{tabular}




\begin{tabular}{|c|c|c|c|c|}
\hline Construct & Item $\mathbf{N}^{\mathbf{o}}$ & Description & Mean & $\begin{array}{l}\text { Standard } \\
\text { Desviation }\end{array}$ \\
\hline \multirow{4}{*}{$\begin{array}{l}\text { Perceived } \\
\text { support for } \\
\text { enhancing } \\
\text { social ties }\end{array}$} & PSES_1 & $\begin{array}{l}\text { I think that blogs are } \\
\text { useful tools in infant } \\
\text { education. }\end{array}$ & 6.00 & 1.10 \\
\hline & PSES _2 & $\begin{array}{l}\text { In my opinion, blogs } \\
\text { can promote interaction } \\
\text { between the school and } \\
\text { the family. }\end{array}$ & 6.28 & 0.97 \\
\hline & PSES_3 & $\begin{array}{l}\text { Using blogs can help } \\
\text { deepen relationships } \\
\text { in the educational } \\
\text { community (teachers, } \\
\text { students, families). }\end{array}$ & 6.23 & 1.04 \\
\hline & PSES _4 & $\begin{array}{l}\text { In my opinion, blogs can } \\
\text { help me establish closer } \\
\text { relationships with my } \\
\text { classmates. }\end{array}$ & 5.40 & 1.31 \\
\hline \multirow{4}{*}{$\begin{array}{l}\text { Intention to } \\
\text { using blogs }\end{array}$} & INCUB_1 & $\begin{array}{l}\text { If I can, I would like to } \\
\text { continue using blogs } \\
\text { in my future learning } \\
\text { activities. }\end{array}$ & 5.54 & 1.25 \\
\hline & INCUB_2 & $\begin{array}{l}\text { If possible, I would prefer } \\
\text { to keep using blogs in my } \\
\text { courses in future. }\end{array}$ & 5.32 & 1.27 \\
\hline & INCUB_3 & $\begin{array}{l}\text { I strongly recommend } \\
\text { that other students use } \\
\text { blogs for learning. }\end{array}$ & 5.45 & 1.28 \\
\hline & INCUB_4 & $\begin{array}{l}\text { I am going to use blogs } \\
\text { in my academic and/or } \\
\text { professional life in future. }\end{array}$ & 5.83 & 1.26 \\
\hline
\end{tabular}

\section{ANALYSIS AND RESULTS}

In order to test the hypotheses, a multivariate analysis was performed via the production of a structural equation model using partial least squares (PLS). This technique does not require large samples (Hair, Hult, Ringle, \& Sarstedt, 2017) and does not require multivariate normality from the observations (Esposito Vinzi, Trinchera, \& Amato, 2010). 
Chin (2010) made the argument that PLS is an appropriate technique for predicting and evaluating the relationship between latent variables (non observable constructs) from indicators in complex models. It is commonly used in the social sciences, particularly in education (Marcoulides \& Chin, 2013). It is not only for use in an exploratory manner, but can also be a strategy for confirmation of models with a solid theoretical base (Cupani, 2012), such as in this research.

Using PLS requires two phases (Henseler \& Chin, 2010). In the first, the measurement model is analysed and evaluated. In the second, the structural model is produced. The statistical software SmartPLS version 3.2.7 was used for this purpose.

\section{Measurement model}

Ringle, Sarstedt, and Schlittgen (2010) established the need to ensure appropriate reliability and validity (Table 2). Appropriate reliability was achieved with a Cronbach alpha coefficient over 0.70 in all constructs (O'Dwyer \& Bernauer, 2014). For indices of composite reliability values greater than 0.5 confirm the internal reliability of the construct, a target that the data in this study met comfortably.

In terms of convergent validity, the average variance extracted (Table 2) ranges between 0.68 and 0.82 , higher than the 0.50 advised by Hair, Ringle, and Sartedt (2011) for more than $50 \%$ of the variance of the construct to be due to the indicators. The standardised item loadings also surpass the 0.505 level.

Table 2

Reliability and convergent validity of the indicators and model constructs

\begin{tabular}{lllll}
\hline & \multicolumn{2}{c}{ RELIABIITY } & \multicolumn{2}{c}{ CONVERGENT VALIDITY } \\
\cline { 2 - 5 } $\begin{array}{l}\text { Constructs and } \\
\text { indicators (items) }\end{array}$ & $\begin{array}{l}\text { Cronbach's } \\
\text { Alpha }\end{array}$ & $\begin{array}{l}\text { Composite } \\
\text { reliability }\end{array}$ & $\begin{array}{l}\text { AVE.- Average } \\
\text { variance } \\
\text { extracted }\end{array}$ & $\begin{array}{l}\text { Item } \\
\text { Loadings }\end{array}$ \\
\hline Perceived self-efficacy: & 0.843 & 0.895 & 0.681 & 0.831 \\
PSEF_1 & & & & 0.872 \\
PSEF_2 & & & & 0.782 \\
PSEF_3 & & & 0.758 & 0.814 \\
PSEF_4 & & & & 0.878 \\
Perceived ease of use: & 0.893 & 0.926 & & 0.894 \\
PEOU_1 & & & & 0.855 \\
PEOU_2 & & & & 0.857 \\
PEOU_3 & & &
\end{tabular}




\begin{tabular}{|c|c|c|c|c|}
\hline \multirow[b]{2}{*}{$\begin{array}{l}\text { Constructs and } \\
\text { indicators (items) }\end{array}$} & \multicolumn{2}{|c|}{ RELIABIITY } & \multicolumn{2}{|c|}{ CONVERGENT VALIDITY } \\
\hline & $\begin{array}{l}\text { Cronbach's } \\
\text { Alpha }\end{array}$ & $\begin{array}{l}\text { Composite } \\
\text { reliability }\end{array}$ & $\begin{array}{l}\text { AVE.- Average } \\
\text { variance } \\
\text { extracted }\end{array}$ & $\begin{array}{l}\text { Item } \\
\text { Loadings }\end{array}$ \\
\hline Perceived usefulness: & 0.867 & 0.909 & 0.716 & \\
\hline PUSS_1 & & & & 0.838 \\
\hline PUSS_2 & & & & 0.862 \\
\hline PUSS_3 & & & & 0.869 \\
\hline PUSS_4 & & & & 0.814 \\
\hline Perceived playfulness: & 0.879 & 0.916 & 0.733 & \\
\hline PPLY_1 & & & & 0.798 \\
\hline PPLY_2 & & & & 0.843 \\
\hline PPLY_3 & & & & 0.874 \\
\hline PPLY_4 & & & & 0.908 \\
\hline $\begin{array}{l}\text { Personal outcome } \\
\text { expectations: }\end{array}$ & 0.765 & 0.865 & 0.682 & \\
\hline POUT_1 & & & & 0.834 \\
\hline POUT_2 & & & & 0.875 \\
\hline POUT_3 & & & & 0.766 \\
\hline Attitude toward blogs: & 0.947 & 0.959 & 0.825 & \\
\hline ATTI_1 & & & & 0.889 \\
\hline ATTI_2 & & & & 0.915 \\
\hline ATTI_3 & & & & 0.909 \\
\hline ATTI_4 & & & & 0.911 \\
\hline ATTI_5 & & & & 0.918 \\
\hline $\begin{array}{l}\text { Perceived support for } \\
\text { enhancing social ties: }\end{array}$ & 0.860 & 0.906 & 0.710 & \\
\hline PSES_1 & & & & 0.765 \\
\hline PSES _2 & & & & 0.911 \\
\hline PSES _3 & & & & 0.929 \\
\hline PSES _4 & & & & 0.751 \\
\hline Intention to using blogs: & 0.930 & 0.950 & 0.827 & \\
\hline INCUB_1 & & & & 0.934 \\
\hline INCUB_2 & & & & 0.942 \\
\hline INCUB_3 & & & & 0.889 \\
\hline INCUB_4 & & & & 0.871 \\
\hline
\end{tabular}


In order to verify that the measurement model was appropriate, discriminant validity was examined using two complementary analyses. Firstly, a matrix was produced of factor loadings and cross-factor loadings, confirming that the factor loadings were greater. In other words, the model indicators exhibited better correlation with their own construct than with others. We also analyzed whether the square root of the AVE of each construct was greater than the correlation between that construct and all the others.

\section{Structural model}

After verifying that the psychometric requirements for reliability and validity had been met, the structural model was created to examine the research hypotheses. The results are shown in Figure 2 and in Table 3

Authors such as Chin (1998) established indexes of 0.67 (substantial), 0.33 (moderate) and 0.10 (weak) for $\mathrm{R}^{2}$, which means that overall, the predictive value of the model is adequate. Figure 2 shows that $71.1 \%$ of the variance of the construct intention to using blogs is explained by the latent variables attitude towards blogs and perception of playfulness; 55\% of the variance of the latent variable perception of playfulness is explained by attitude towards blogs, a latent variable which is in turn $56 \%$ explained by the construct perceived usefulness and $50.9 \%$ by perceived ease of use. Finally, $30.6 \%$ of the endogenous variable perceived usefulness is explained by personal outcome expectations.

$Q^{2}$ was used to evaluate the predictive relevance of each of the model's endogenous variables. Taking the values proposed by Doleck, Bazelais, and Lemai (2017) as a reference and given that all of the $Q^{2}$ values were greater than zero, the conclusion is that there is adequate predictive relevance (Figure 2). 


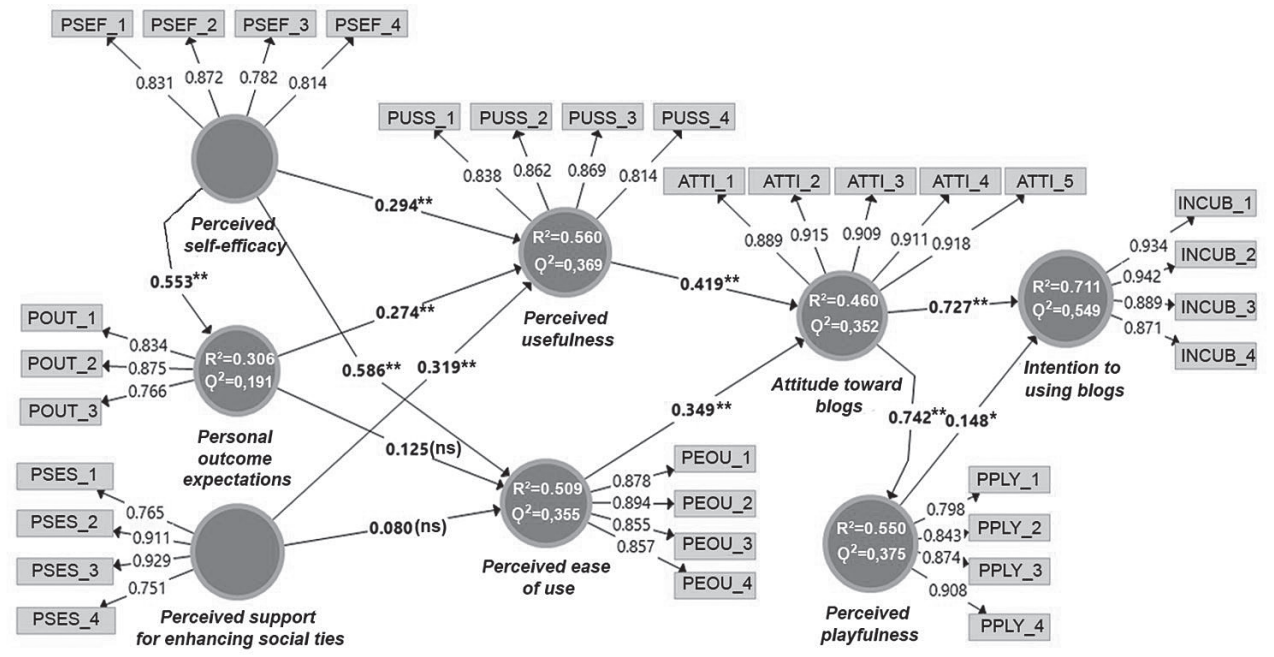

Figure 2. Results of the PLS analysis of the proposed model

Note: $* *=$ significant at $p<0.001 ; *=$ significant at $p<0.01 ; \mathrm{ns}=$ not significant

The results in Table 3 show that, of the twelve hypotheses, the model supports all except two ( $\mathrm{H} 2 \mathrm{~b}$ and $\mathrm{H} 3 \mathrm{~b}$ ). Table 3 also gives the standardised regression coefficients $(\mathbb{\nabla})$, associated $\mathrm{T}$ statistics, and the levels of significance ( $p$-value), allowing a determination to be made of whether the hypotheses are supported by the proposed model.

In addition, $f^{2}$ coefficients were calculated to analyse the effect size of the relationships between variables (Chin, Marcolin, \& Newted, 2003). Cohen's (1988) criteria were used which states values of 0.35 (large), 0.15 (medium), and 0.02 (small).

Table 3

Summary of results and hypothesis testing

\begin{tabular}{lllllll}
\hline Hypothesis & Hypothesized path & $\boldsymbol{\beta}$ & $\begin{array}{l}\text { T } \\
\text { Statistic }\end{array}$ & $P$-value & $\boldsymbol{f}^{2}$ & Result \\
\hline H1a & $\begin{array}{l}\text { Perceived self-efficacy } \rightarrow \\
\text { Perceived usefulness }\end{array}$ & 0.294 & 4.627 & $0.000 * *$ & 0.124 & Supported \\
H1b & $\begin{array}{l}\text { Perceived self-efficacy } \rightarrow \\
\text { Perceived ease of use }\end{array}$ & 0.586 & 7.043 & $0.000 * *$ & 0.441 & Supported \\
H2a & $\begin{array}{l}\text { Personal outcome } \\
\text { expectations } \rightarrow \text { Perceived } \\
\text { usefulness }\end{array}$ & 0.274 & 4.204 & $0.000 * *$ & 0.095 & Supported \\
& & & & & &
\end{tabular}




\begin{tabular}{|c|c|c|c|c|c|c|}
\hline Hypothesis & Hypothesized path & $\beta$ & $\begin{array}{l}\mathbf{T} \\
\text { Statistic }\end{array}$ & $P$-value & $\boldsymbol{f}^{2}$ & Result \\
\hline $\mathrm{H} 2 \mathrm{~b}$ & $\begin{array}{l}\text { Personal outcome } \\
\text { expectations } \rightarrow \text { Perceived } \\
\text { ease of use }\end{array}$ & 0.125 & 1.456 & 0.146 & 0.018 & $\begin{array}{l}\text { Not } \\
\text { Supported }\end{array}$ \\
\hline $\mathrm{H} 3 \mathrm{a}$ & $\begin{array}{l}\text { Perceived support for } \\
\text { enhancing } \rightarrow \text { Perceived } \\
\text { usefulness }\end{array}$ & 0.319 & 4.742 & $0.000 * *$ & 0.132 & Supported \\
\hline $\mathrm{H} 3 \mathrm{~b}$ & $\begin{array}{l}\text { Perceived support for } \\
\text { enhancing } \rightarrow \text { Perceived } \\
\text { ease of use }\end{array}$ & 0.080 & 1.173 & 0.241 & 0.008 & $\begin{array}{l}\text { Not } \\
\text { Supported }\end{array}$ \\
\hline $\mathrm{H} 4$ & $\begin{array}{l}\text { Perceived self-efficacy } \\
\rightarrow \text { Personal outcome } \\
\text { expectations }\end{array}$ & 0.553 & 10.787 & $0.000 * *$ & 0.441 & Supported \\
\hline H5 & $\begin{array}{l}\text { Perceived usefulness } \rightarrow \\
\text { Attitude toward blogs }\end{array}$ & 0.419 & 6.525 & $0.000 * *$ & 0.226 & Supported \\
\hline H6 & $\begin{array}{l}\text { Perceived ease of use } \rightarrow \\
\text { Attitude toward blogs }\end{array}$ & 0.349 & 5.046 & $0.000 * *$ & 0.157 & Supported \\
\hline $\mathrm{H} 7$ & $\begin{array}{l}\text { Attitude toward blogs } \rightarrow \\
\text { Intention to using blogs }\end{array}$ & 0.727 & 14.190 & $0.000 * *$ & 0.822 & Supported \\
\hline $\mathrm{H} 8$ & $\begin{array}{l}\text { Attitude toward blogs } \rightarrow \\
\text { Perceived playfulness }\end{array}$ & 0.742 & 18.221 & $0.000 * *$ & 1,224 & Supported \\
\hline H9 & $\begin{array}{l}\text { Perceived playfulness } \rightarrow \\
\text { Intention to using blogs }\end{array}$ & 0.148 & 2.709 & $0.007 *$ & 0.034 & Supported \\
\hline
\end{tabular}

Note: $* *=$ significant at $p<0.001 ; *=$ significant at $p<0.01$

The goodness of fit of the structural model was evaluated using the SRMR (Standardised Root Mean Square Residual), which according to Henseler, Hubona, and Ray (2016), is the only criterion of overall model fit. This gave a value of 0.06 , which is lower than the 0.08 which indicates a good fit to the model.

\section{DISCUSSION}

Taken as a whole, the proposed research model exhibits a good level of prediction, supporting ten of the twelve suggested hypotheses. More specifically, the results show that students' perceived self-efficacy in the use of blogs has a positive, significant relationship, with a moderate effect size, to students' perceptions of blogs' usefulness (H1a; $\left.\beta=0.294 ; p<0.001 ; f^{2}=0.124\right)$. This is in line with research by Ashtari and Eydgahi (2017), which showed perceived self-efficacy to be a significant factor that is positively correlated with the ease of use of cloud-based technologies, and also a fundamental 
variable to consider when determining whether students will adopt new technologies to improve their learning. On similar lines, researchers such as Srisupawong, Koul, Neanchaleay, Murphy, and Francois (2018) emphasised the importance of students' beliefs about self-efficacy in the use of technology, and demonstrated how those beliefs are influenced by factors such as the learning environment, resources, and sources of information available to the students.

A significant, positive relationship with a large effect size was found between the students' perceptions of self-efficacy and the perceived ease of use of blogs (H1b; $\left.\beta=0.586 ; p<0.001 ; f^{2}=0.441\right)$. This result supports the idea that, as Ifinedo (2107) indicated, students with high levels of self-efficacy in blog use probably integrate these tools into their learning contexts more easily precisely due to the ease with which they use them.

Significant values, albeit with small effect sizes, were found between personal outcome expectations and the perception of usefulness $(\mathrm{H} 2 \mathrm{a}$; $\left.\beta=0.274 ; p<0.001 ; f^{2}=0.095\right)$. This shows that students agree that using blogs to learn significant subject content is useful for improving learning. Similar findings have been confirmed in research by Fernández-Cardador, et al. (2014).

No significant relationship, however, was found between personal outcome expectations and perceived ease of use (H2b; $\beta=0.125 ; p=0.146$; $f^{2}=0.018$ ). Ifinedo (2017) interpreted a similar result by saying that students who wanted to be rewarded for their hard work on the blog would be less concerned about how difficult they found the work compared to how they benefited from using blogs in achieving the results they hoped for.

A high level of significance was found, with a moderate effect size, in the relationship between perceived support for enhancing social ties and perceived usefulness of blogs (H3a; $\left.\beta=0.319 ; p<0.001 ; f^{2}=0.132\right)$. One might say that students who think about using blogs as collaborative tools that facilitate interaction between classmates and other educational agents find it easier to appreciate the benefits of using these applications for learning. These results tie into various studies which have looked into the importance of using blogs as systems to improve social relationships and collaboration in university contexts (Dapía \& Escudero, 2014; Deng \& Yuen, 2011). Despite that, no evidence was found that would support perceived support for enhancing social ties having a significant, positive effect on the perceived ease of use of blogs ( $\left.\mathrm{H} 3 \mathrm{~b} ; \beta=0.080 ; p=0.241 ; f^{2}=0.008\right)$. This might be due to the majority of students having created their own blogs and having previously received a wide range of training and support materials from the teachers -as they reported in the self-evaluations-. 
The data show a significant, positive relationship, with a large effect size, between perceived self-efficacy and personal outcome expectations (H4; $\beta=0.553 ; p<0.001 ; f^{2}=0.441$ ). This reinforces the literature, which suggests that self-efficacy is generally related to high levels of success (Schunk, Meece, \& Pintrich, 2014).

Both the perceived usefulness of blogs (H5; $\beta=0.419 ; p<0.001$; $\left.f^{2}=0.226\right)$ and their ease of use $\left(H 6 ; \beta=0.349 ; p<0.001 ; f^{2}=0.157\right)$ exhibited a significant, positive influence (with a moderate effect size) on students' attitudes towards blogs. Goktas and Demirel (2011) concluded after a mixed longitudinal study in first year teaching students that blogs which were simple and easy to use, were more likely to encourage positive attitudes towards blogs, even if students reported limited technical skills. Similarly, other studies based on the technology acceptance model suggest that the perception of usefulness and ease of use have a positive impact on attitudes towards blogs (Ifinedo, 2018a; Fan, Haung, Hsu, \& Chen, 2013).

The data also show that students with favourable attitudes towards blogs in learning environments are much more likely to continue using the technology in their academic activities $\left(\mathrm{H} 7 ; \beta=0.727 ; p<0.001 ; f^{2}=0.822\right)$. In parallel, students who are more favourable to using blogs tend to be more likely to use posts as catalysts to stimulate curiosity and imagination, as well as to participate in a playful manner in an enjoyable learning environment (H8; $\left.\beta=0.742 ; p<0.001 ; f^{2}=1.224\right)$. These results are very similar to those from research by Hung, et al. (2016).

Likewise, the results confirm that students who enjoy using blogs are more likely to continue using these tools for learning (H9; $\beta=0.148 ; p<0.01$; $\left.f^{2}=0.034\right)$. This is a hypothesis which has also been confirmed in research by Lin and Li (2014).

In short, the results show the importance of working with blogs to encourage their addition to the repertoire of resources making up each student's learning ecology and contributing to their use in learning throughout students' lives.

\section{LIMITATIONS AND FUTURE LINES OF RESEARCH}

One of the limitations of this study was that the participants were first-year students of infant education, and it would be better to have a wider sample covering all of the years of the degree, and even higher degrees (e.g. masters and postdoctoral degrees) in order to be able to carry out comparisons and look at whether the results can be replicated. It would 
also be very useful to carry out a longitudinal study which would be able to look at whether the students' intentions to using blogs are maintained over time (not just in their initial training, but also in their transition to the professional environment).

Future research should address a larger number of constructs which would make the model more robust, these may include: student learning styles, student satisfaction and perceived impact on learning, amongst others. In addition, to make the research as generally applicable as possible, subsequent studies should use samples which are representative of students from other countries and universities (both on-site and distance learning), in which variables could be controlled such as: type of subject, group size, student characteristics, use of the same support materials, and the use of the same teaching methodology.

\section{CONCLUSIONS AND RECOMMENDATIONS}

Despite the limitations, the results of this study as a whole confirm and expand on findings from other similar research (Ifinedo 2018a, 2018b; Lu \& Hsiao, 2007), adding to the scant literature related to university students' intentions to using blogs to support their future learning.

The model used leads us to the conclusion that there are particularly important factors which influence students' decisions to using blogs for learning. The importance of intrinsic motivational factors, such as perceived playfulness, has been demonstrated. Recent research by Mohd, Fei, and Zahirah (2018) and López and Silva (2016) has demonstrated that this is a key element which modulates students' intentions to use technology owing in large part to the possibility it gives students to be able to learn via a more interactive, appealing system.

Other variables such as perceived usefulness, perceived ease of use, and attitude (key constructs making up part of the classic technology acceptance model formulated by Davis, 1989) have also been shown to be significant predictors of blog and other technology use. In fact there is a broad consensus in the scientific community that these factors are core aspects which influence students' behaviour when it comes to using certain technological tools or not (Cabero-Almenara \& Pérez, 2018).

The proposed model also included variables from social-cognitive theory (Bandura, 1986), such as self-efficacy, personal outcome expectations, and perceived support for enhancing social ties, which were also key 
constructs as other researchers have indicated in previous studies (Ifinedo, 2017).

Finally, the results of this study represent a roadmap which invites consideration of those aspects which might encourage future infant-school teachers to using blogs for learning. Below are some useful recommendations for educators of future teachers:

- Materials and training sessions should be created for initial training sessions so that students do not only learn basic or advanced blog management, but rather are also exposed to the educational and professional possibilities blogs offer (Pinya \& Roselló, 2014).

- It is essential during the process of using blogs that students are given clear orientation by their teachers which will allow them to see the usefulness of the tasks they are set and how to approach them effectively (Lee, 2018).

- Instructors must actively participate in students' blogs, providing continual feedback which serves as a scaffold for constructivist and connectivist learning.

- Teachers should propose varied, different training activities which must be seen by the students as authentic and useful.

- Use of collaborative methodologies encourages the feeling of belonging to the class-group, encouraging horizontal communication, motivation to participate, and both individual and collective expression (Santoveña, 2011).

- Situations should be devised in which students really play active and reflexive roles, encouraging self-evaluation and co-evaluation of their own practice (Dapía \& Escudero, 2014).

- Blogs must be included as a significant part of the teaching-learning process framework, in connection with the use of other social tools and avoiding only being used in isolated or unconnected curriculum activities (Williams \& Jabobs, 2004).

- The intention to continue behaviour which will perpetuate the use of blogs among future infant education teachers will depend to a large extent on the attitude that these students demonstrate towards these tools. Clearly demonstrating or examining their academic and professional possibilities has been shown to be fundamental. 


\section{ACKNOWLEDGEMENTS}

This article was produced within the framework of the project "How the best university teachers learn in the digital age: the impact of learning ecologies on teaching quality", partly financed by the Spanish Ministry of the Economy, Industry and Business (Reference: EDU2015-67907-R). 


\section{REFERENCES}

Álvarez, G., y Bassa, L. (2013). TIC y aprendizaje colaborativo: el caso de un blog de aula para mejorar las habilidades de escritura de estudiantes preuniversitarios. Revista de Universidad y Sociedad del Conocimiento, 10(2), 5-19. 10.7238/ rusc.v10i2.1740

Avci, U., \& Askar, P. (2012). The comparison of the opinions of university students on the usage of blog and wiki for their courses. Educational Technology \& Society, 15(2), 194-205.

Ashtari, S., \& Eydgahi, A. (2017). Student perceptions of cloud applications effectiveness in higher education. Journal of Computational Science, 23, 173-180. 10.1016/j.jocs.2016.12.007

Bandura, A. (1986). Social foundations of thought and action: A social cognitive theory. Englewood Cliffs, NJ, USA: Prentice-Hall

Cabero-Almenara, J., y Pérez, J. L. (2018). Validación del modelo TAM de adopción de la Realidad Aumentada mediante ecuaciones estructurales. Estudios sobre Educación, 34, 129-153. 10.15581/004.34.129-153

Cakir, H. (2013). Use of blogs in preservice teacher education to improve student engagement, Computers \& Education, 68, 244-252. 10.1016/j. compedu.2013.05.013

Chen, C.P., Lai, H.M., \& Ho. C.Y. (2015). Why Do Teachers Continue to Use Teaching Blogs? The Roles of Perceived Voluntariness and Habit. Computers \& Education, 82, 236-249. 10.1016/j.compedu.2014.11.017

Chin, W.W. (1998). The Partial Least Squares Approach to Structural
Equation Modeling. In G. A. Marcoulides (Ed.), Modern Methods for Business Research. (pp. 295- 336). New York, NY, USA: Psychology Press

Chin, W.W. (2010). How to write up and report PLS analyses. In V. Esposito Vinzi, W.W. Chin, Henseler, J., \& H. Wang (Eds.), Handbook of partial least squares: Concepts, methods and applications (pp. 655-690). Berlin, Germany: Springer. 10.1007/978-3540-32827-8

Chin, W.W., Marcolin, B.L., \& Newsted, P.R. (2003). A partial least squares latent variable modeling approach for measuring interaction effects: results from a Monte Carlo simulation study and an electronic-mail emotion/ adoption study. Information Systems Research, 14(2), 189-217. 10.1287/ isre.14.2.189.16018

Cho, M.-H., Lim, S., \& Lee, K. (2017). Does documenting the regulation process on a blog enhance pre-service teachers' self- and co-regulation in a collaborative project? Australasian Journal of Educational Technology, 33(4), 166-179. 10.14742/ajet.2996

Cohen, J. (1988). Statistical power analysis for the behavioral sciences. Hillsdale, NJ, USA: Lawrence Erlbaum Associates

Cupani, M. (2012). Análisis de Ecuaciones Estructurales: conceptos, etapas de desarrollo y un ejemplo de aplicación. Revista Tesis, 2(1), 186199.

Dapía, M., y Escudero, R. (2014). Aprendizaje colaborativo mediante el uso de edublog en la enseñanza universitaria. Valoración de una experiencia. Enseñanza \& Teaching, 32(2), 53-72. 10.14201/et20143215372 
Davis, F.D. (1989). Perceived usefulness, perceived ease of use, and user acceptance of information technology. MIS Quarterly, 13(3), 319-340. $10.2307 / 249008$

Deng, L., \& Yuen, H.K. (2011). Towards a framework for educational affordances of blogs. Computers \& Education, 56(2), 441-451. 10.1016/j. compedu.2010.09.005

Doleck, T., Bazelais, P., \& Lemani, D. J. (2017). Examining the antecedents of social networking sites use among CEGEP students. Education and Information Technologies, 22(5), 21032123. 10.1007/s10639-016-9535-4

Durán Medina, J.F. (2011). La contribución del edublog como estrategia didáctica. Electronic Journal of Research in Educational Psychology, 9(23) 331-356. 10.25115/ ejrep.v9i23.1440

Esposito Vinzi, V., Trinchera, L., \& Amato, S. (2010). PLS path modeling: From foundations to recent developments and open issues for model assessment and improvement. In V. Esposito Vinzi, J. Henseler, \& H. Wang, (Eds.). Handbook of partial least squares: Concepts, methods and applications (pp. 47-82) Berlin, Germany: Springer. 10.1007/978-3540-32827-8

Fan, W.S., Haung, Y.K., Hsu, H.C., \& Chen, C.C. (2013). An analysis of de Blog-User' attitude employing structural equation modeling combine TAM and TPB model. Applied Mechanics and Materials, 411-414, 90-93. 10.4028/www.scientific.net/ AMM.411-414.90

Fernández-Cardador, P., HernándezGarcía, A., \& Iglesias-Pradas, S. (2014). A "Collaborative Me" Crossroad: Individual Beliefs and the Adoption of Corporate Blogs. In C. Hernández, A. López-Paredes, J. Pérez-Ríos (Eds.), Managing Complexity. Lecture Notes in Management and Industrial Engineering (pp.19-26). Geneve, Switzerland: Springer, Cham. 10.1007/978-3-319-04705-8_2

Garcia, E., Moizer, J. Wilkins, S., \& Haddoud, M.Y. (2019). Student learning in higher education through blogging in the classroom. Computers \& Education, 136, 61-74. 10.1016/j. compedu.2019.03.011

García-Martín, S., y Cantón-Mayo, I. (2019). Uso de tecnologías y rendimiento académico en estudiantes adolescentes. Comunicar, 59, 73-81. 10.3916/C59-2019-07

Goktas, Y., \& Demirel, T. (2012). Blogenhanced ICT courses: Examining their effects on prospective teachers' ICT competencies and perceptions. Computers \& Education, 58, 908-917. 10.1016/j.compedu.2011.11.004

González-Sanmamed, M., Sangrà, A., Souto-Seijo, A., y Estévez, I. (2018). Ecologías de aprendizaje en la era digital: desafíos para la educación superior. Publicaciones, 48(1), 11-38. 10.30827/publicaciones.v48i1.7329

Hair, J.F., Hult, G.T.M., Ringle, C.M., \& Sarstedt, M. (2017). A primer on partial least squares structural equation modeling (PLS-SEM). Thousand Oaks, CA, USA: Sage

Hair, J., Ringle, C., \& Sarstedt, M. (2011). PLS-SEM: Indeed a silver bullet. The Journal of Marketing Theory and Practice, 19(2), 139-152. 10.2753/ mtp1069-6679190202

Henseler, J., \& Chin, W.W. (2010). A comparison of approaches for the analysis of interaction effects between latent variables using partial least squares path modeling. 
PABLO-CÉSAR MUÑOZ-CARRIL, MERCEDES GONZÁLEZ-SANMAMED, EDUARDO-JOSÉ FUENTES-ABELEDO

USE OF BLOGS FOR PROSPECTIVE EARLY CHILDHOOD TEACHERS

Structural Equation Modeling: A Multidisciplinary Journal, 17(1), 82109. 10.1080/10705510903439003

Henseler, J., Hubona, G., \& Ray, A. R. (2016). Using PLS path modeling in new technology research: updated guidelines. Industrial Management \& Data Systems, 116(1), pp.2-20, 10.1108/ IMDS-09-2015-0382

Hung, S.Y., Tsai, J.C.A., \& Chou, S.T. (2016). Decomposing perceived playfulness: A contextual examination of two social networking sites. Information \& Management, 53(6), 698-716. 10.1016/j.im.2016.02.005

Ifinedo, P. (2017). Examining students' intention to continue using blogs for learning: Perspectives from technology acceptance, motivational, and socialcognitive frameworks. Computers in Human Behavior, 72, 189-199. 10.1016/j.chb.2016.12.049

Ifinedo, P. (2018a). Determinants of students' continuance intention to use blogs to learn: an empirical investigation. Behaviour \& Information Technology, 37(4), 381392. 10.1080/0144929X.2018.1436594

Ifinedo, P. (2018b). Roles of perceived fit and perceived individual learning support in students' weblogs continuance usage intention. Journal of Educational Technology in Higher Education, 15(7), 1-18. 10.1186/ s41239-018-0092-3

Jackson, N. (2016). Exploring learning ecologies. London, UK: Chalk Mountain

Khan, A. (2017). Blog-based professional development of English teachers in Mumbai: The potential of innovative practice under scrutiny. Australasian Journal of Educational Technology, 33(4), 88-106. 10.14742/ajet.2784
Lai, C., Wang, Q., \& Lei, J. (2012). What factors predict undergraduate students'use of technology for learning? Computers \& Education, 59(2), 333-341. $\quad 10.1016 / \mathrm{j}$. compedu.2012.03.006

Lee, Y. (2018). The influence of structured guidance on pre-service teachers' blog writing. Australasian Journal of Educational Technology, 34(3), 30-38. 10.14742/ajet.3094

Lin, T.T.C., \& Li, L. (2014). Perceived Characteristics, Perceived popularity, and Playfulness: Youth Adoption of Mobile Instant Messaging in China. China Media Research, 10(2), 60-71.

Lu, H.P., \& Hsiao, K.L. (2007). Understanding intention to continuously share information on weblogs. Internet Research, 17(4), 345361. 10.1108/10662240710828030

López, F.A., y Silva, M.M. (2016). Factores que inciden en la aceptación de los dispositivos móviles para el aprendizaje en educación superior. Estudios sobre Educación, 30, 175-195. 10.15581/004.30.175-195

Marcoulides, G.A., \& Chin, W.W. (2013). You write, but others read: Common methodological misunderstandings in PLS and related methods. In H. Abdi, W.W. Chin, V. Esposito, G. Russolillo, \& L. Trinchera (Eds.), New perspectives in Partial Least Squares and related methods (pp. 31-64). New York, USA: Springer. 10.1007/978-1-4614-8283-3

Marín-Díaz, M.V., \& Gomez-Parra, E. (2015). Edublogs in the Development of the European Higher Education Area: An Initiative in the Primary Education Degree Course at the University of Cordoba (Spain). Procedia- Social and Behavioral Sciences, 197, 2251-2256. 10.1016/j.sbspro.2015.07.329 
Mohd, S., Fei, C., \& Zahirah, R. (2018). Factors influencing use of monsoonsim business simulation by UTM undergraduate students. International Journal of Learning and Development, 8(2), 61-79. 10.5296/ijld. v8i2.13073

Muñoz-Carril, P.C. (2019). Los blogs en el ámbito universitario: percepción de su utilidad en la formación inicial de maestros de educación infantil. En J.F. Durán, F.J. Godoy, y J. Rodríguez, (Coords.), Las TIC en las aulas de enseñanza superior, (pp. 285-294). Barcelona: Gedisa.

O’Dwyer, L., \& Bernauer, J. (2014). Quantitative research for the qualitative researcher. California, USA: Sage

Pinya, C., Tur, G., y Rosselló, M. R. (2016). Los blogs en la formación docente inicial. Estudios Pedagógicos, 42(1), 223-233. 10.4067/S071807052016000100014

Pinya, C. \& Rosselló, M. R. (2014). Using blogs to be aware of the development and adoption of professional skills. Education and Information Technologies, 21(5), 1055-1070. 10.1007/s10639-014-9367-z

Ringle, C.M., Sarstedt, M., \& Schlittgen, R. (2010). Finite mixture and genetic algorithm segmentation in partial least squares path modeling: Identification of multiple segments in a complex path model. In A. Fink, B. Lausen, W. Seidel, \& A. Ultsch (Eds.), Advances in data analysis, data handling and business intelligence (pp. 167-176). Berlin, Germany: Springer

Rohatgi, A., Scherer, R., \& Hatlevik, O.E. (2016). The role of ICT self- efficacy for students' ICT use and their achievement in a computer and information literacy test. Computers \& Education, 102, 103-116. 10.1016/j. compedu.2016.08.001

Santoveña, S. (2011). Incidencia de los nuevos alfabetismos en la mejora de la calidad de la enseñanza: El caso de los blogs. Aula Abierta, 39(2), 59-68.

Sáinz, M., \& Eccles, J. (2012). Selfconcept of computer and math ability: Gender implications across time and within ICT studies. Journal of Vocational Behavior, 80(2), 486-499. 10.1016/j.jvb.2011.08.005

Schunk, D.H., Meece, J.L. \& Pintrich, P.R. (2014). Motivation in education: Theory, Research, and Applications (4th ed.). Harlow, USA: Pearson

Srisupawong, Y., Koul, R., Neanchaleay, J., Murphy, E., \& Francois, E.J. (2018). The relationship between sources of self-efficacy in classroom environments and the strength of computer. Education and Information Technologies, 23(2), 681-703. 10.1007/ s10639-017-9630-1

Sullivan, M., \& Longnecker, N. (2014). Class blogs as a teaching tool to promote writing and student interaction. Australasian Journal of Educational Technology, 30(4), 390401. 10.14742/ajet.322

Williams, J.B., \& Jacobs, J. (2004). Exploring the use of blogs as learning spaces in the higher education sector. Australasian Journal of Educational Technology, 20(2), 232-247.:10.14742/ ajet. 1361 


\section{PERFIL ACADÉMICO Y PROFESIONAL DE LOS AUTORES}

Pablo-César Muñoz-Carril. Profesor Contratado Doctor en el área de Didáctica y Organización Escolar. Departamento de Pedagogía y Didáctica. Facultad de Formación del Profesorado. Universidad de Santiago de Compostela. Sus líneas de investigación son: formación y desarrollo del profesorado, integración e innovación con tecnologías en el ámbito educativo, e-learning y trabajo colaborativo en línea. Es coordinador del Grupo de Investigación Educativa MESTURA de la Universiad de Santiago de Compostela.

Mercedes González-Sanmamed. Catedrática del área de Didáctica y Organización Escolar. Departamento de Pedagogía y Didáctica de la Universidad de A Coruña. Campos de investigación: formación del profesorado, integración de las TIC en educación, innovación y mejora educativa. Ha dirigido 16 proyectos competitivos nacionales e internacionales y paticipado en 29. Dirige el grupo de investigación EIRA de la Universidad de A Coruña. Ha publicado 22 libros, 30 capítulos y 77 artículos en revistas indexadas.

Eduardo José Fuentes-Abeledo. Profesor Titular de Universidad en el área de Didáctica y Organización Escolar en la Facultad de Ciencias de la Educación de la Universidad de Santiago de Compostela. Sus principales líneas de investigación se focalizan en la formación del profesorado, educación infantil, prácticum e innovación educativa, realizando numerosas publicaciones en estos campos.

Dirección de los autores: Pablo-César Muñoz-Carril

Facultad de Formación del Profesorado

Universidad de Santiago de Compostela

(Campus de Lugo)

Avda. Ramón Ferreiro, s/n

27002. Lugo. España

E-mail: pablocesar.munoz@usc.es

Mercedes González-Sanmamed

Facultad de Ciencias de la Educación

Universidad de A Coruña

Campus de Elviña, s/n

15071. A Coruña. España

E-mail: mercedes.gonzalez.sanmamed@ udc.es 
PABLO-CÉSAR MUÑOZ-CARRIL, MERCEDES GONZÁLEZ-SANMAMED,

Eduardo-José Fuentes-Abeledo

Facultad de Ciencias de la Educación

Universidad de Santiago de Compostela

(Campus Norte)

Avda. Xoan XXIII, s/n

15782. Santiago de Compostela. España

E-mail: eduardo.fuentes@usc.es

Fecha Recepción del Artículo: 10. Febrero. 2019

Fecha Modificación del Artículo: 09. Junio. 2019

Fecha Aceptación del Artículo: 10. Junio. 2019

Fecha Revisión para Publicación: 19. Junio. 2019 
